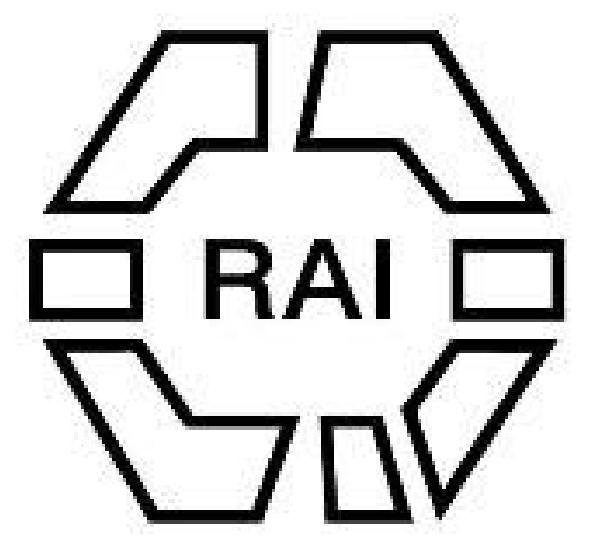

\title{
WILEY
}

\section{Remains of Animals Found in the Dictaean Cave in 1901.}

Author(s): W. Boyd-Dawkins

Source: Man, Vol. 2 (1902), pp. 162-165

Published by: Royal Anthropological Institute of Great Britain and Ireland

Stable URL: http://www.jstor.org/stable/2839533

Accessed: 27-06-2016 02:33 UTC

Your use of the JSTOR archive indicates your acceptance of the Terms \& Conditions of Use, available at

http://about.jstor.org/terms

JSTOR is a not-for-profit service that helps scholars, researchers, and students discover, use, and build upon a wide range of content in a trusted digital archive. We use information technology and tools to increase productivity and facilitate new forms of scholarship. For more information about JSTOR, please contact support@jstor.org.

Royal Anthropological Institute of Great Britain and Ireland, Wiley are collaborating with JSTOR to digitize, preserve and extend access to Man 
the bridge of the nose. The use of face-pendants belongs to the later part of the prehistoric age; and the well-formed figures here may well belong to the dynastic race who brought in artistic work. The use of a hook at the lower end clearly points to a face veil being suspended from it, and indicates that the latter prehistoric people wore face veils, which have been re-introduced by the Arabs into modern Egypt. The shining pendant of white shell or polished copper is evidently akin to the burnished gilt metal ornament now worn on the forehead by Egyptian women, from which the face veil is suspended.

W. M. FLINDERS PE'TRIE.

\section{Crete: Fauna.}

Boyd-Dawkins.

Remains of Animals found in the Dictæan Cave in $1901 . \quad B y 114$
Professor W. Boyd-Dawkins, M.A., D.Sc., F.R.S.

The remains of the animals discovered by Mr. Hogarth in the Dictæan Cave in 1901, and sent to me for identification, present points of considerable interest. They belong partly to animals which have been sacrificed in the Sunctuary of Zeus and partly to animals which have been eaten and left in a lower stratum to form a refuse heap similar in every respect to those invariably found in caves which have been occupied by man. They form an important contribution to our knowledge of the wild and domestic animals in Crete in the Mycenean and early Greek periods.

The conditions of their discovery were as follows: The larger specimens were obtained from an untouched deposit in the atrium of the cave (Journal of Hellenic Studies, Vol. XVII., p. 355) three feet in thickness, which rested upon a layer of gravel. They were associated with fragments of charcoal and of pottery. Three fragments sent along with the bones belong to three flat-bottomed bowls similar to those described by Dr. A. I. Evans in the above paper. One of these, covered with stalagmite, is of thick

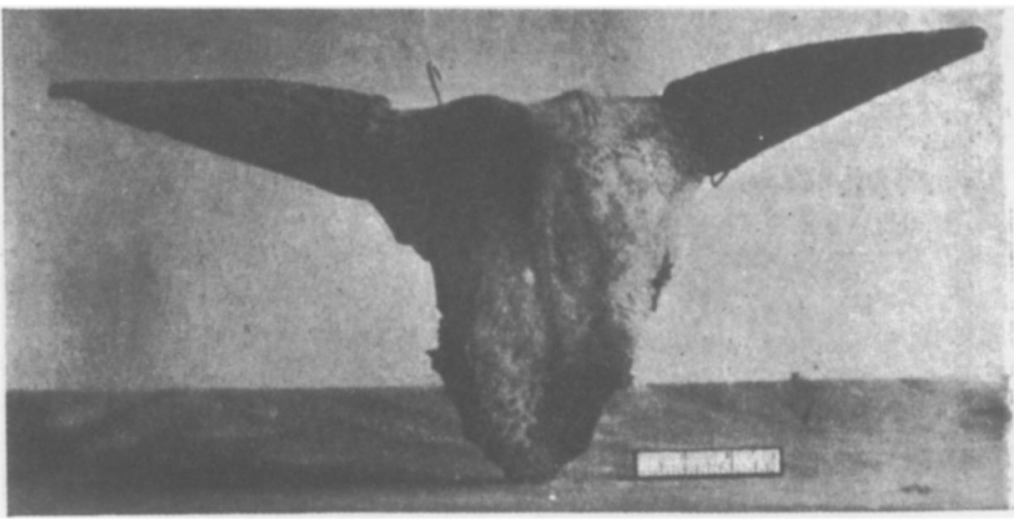

FIG. 1. FRONTLET OF Bos domesticus, VAR creticus. red ware made on the wheel; another is of thin red ware, hand-made, with little stones e mbedded in the paste ; and a third of black pottery, fine in the grain, with a polished surface.

'The smaller, or refuse-heap bones, were derived from the lower stratum, and are therefore of higher antiquity than those obtained from the undisturbed layer above.

The following species have been identified : 1. Bos domesticus, variety creticusA frontlet (Fig. 1) with two perfect horncores, from the upper deposit, belongs to a small domestic bull. It has been hacked off the rest of the skull and has probably been fixed to one of the sides of the shrine or to the altar, as a Bucranium.

It presents the following measurements :-

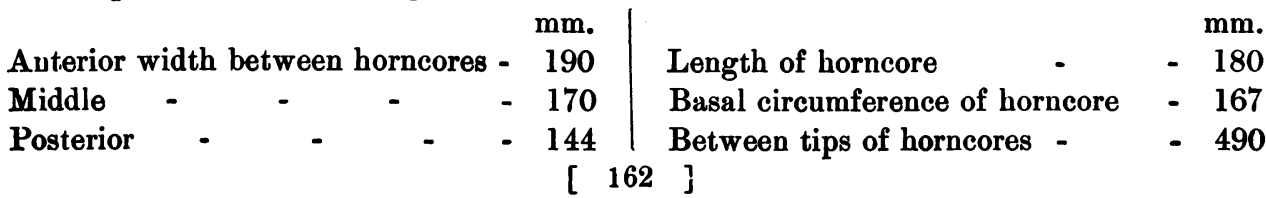


The horncores are short, straight, and stout, and do not project beyond the plane of the frontal bones. The frontals are convex between the bases of the horncores, flattened and convex below. The horncores differ from those of Bos frontosus, described by Nilsson and Rütimeyer, in their shortness, and from Bos brachyceros (B. longifrons, Owen) by their thickness and straightness. They belong to neither of these domesticated breeds. They are, however, identical with those of the head of a bull on the coins of Phocis, of Thessaly, and of Samos (Ridgeway, Early Age of Greece, Vol. I., p. 334). The upper of three oxheads (Schuchardt, Schlieman's Excavations, p. 282) figured along with the head of an ape, and with cuttle-fishes on a gold ring, found in Mycenæ, bears similar though larger horncores, and probably belongs to the same breed as the specimen under consideration. The other two, with doubly curved horns, belong to the larger oxen of the type of the wild urus, the hunting and the taming of which is represented so well in the famous golden cups from the Vaphio tomb.

This frontlet undoubtedly belongs to a breed largely kept in ancient Greece, which for purposes of identification may be named Bos creticus.

The following remains, from the refuse heap in the lower stratum, may probably be referred to the same domestic variety of oxen. Fragments of a lower jaw, three lower jaws of calves with milk teeth, five broken long bones, two phalanges, and a broken metatarsal. Some of the bones have been scraped. One left upper maxillary with teeth was also found, and three upper teeth* :-

2. Capra agagrus, $\dagger$ the wild goat, formerly abundant in the wild state in the Mediterranean, but now found in Europe only in Crete and some of the Cyclades, and in the higher mountains of Asia Minor, is represented by one frontlet and two perfect horncores belonging to males, a skull of a young female, and the frontlet of a kid, and one horncore of adult cut off from the head. All these are probably domesticated varieties, the sole difference between wild and domestic being a question merely of size.

In the following table the principal measurements of the horncores will be found in millimetres :-

\begin{tabular}{|c|c|c|c|c|c|c|c|c|c|}
\hline \multirow{2}{*}{$\begin{array}{l}\text { Anterior width between } \\
\text { horncores. }\end{array}$} & \multicolumn{3}{|c|}{ He Goat. } & \multirow{2}{*}{$\begin{array}{r}\begin{array}{c}\text { She } \\
\text { Goat. }\end{array} \\
34\end{array}$} & \multirow{3}{*}{$\begin{array}{l}\text { Distance of tips - } \\
\text { Basal measurement for } \\
\text { front to back rounded } \\
\text { angle. }\end{array}$} & \multicolumn{3}{|c|}{ He Goat. } & \multirow{2}{*}{$\begin{array}{r}\text { She } \\
\text { Goat. } \\
100 \\
18\end{array}$} \\
\hline & 16 & 22 & 32 & & & 290 & - & - & \\
\hline $\begin{array}{l}\text { horncores. } \\
\text { Posterior width between } \\
\text { horncores. }\end{array}$ & 63 & - & - & 53 & & 64 & 63 & 60 & 18 \\
\hline Length of horncores & 400 & 400 & $420+$ & 150 & Measurement at right & 36 & 36 & 45 & - \\
\hline $\begin{array}{l}\text { Basal circumference of } \\
\text { horncores. }\end{array}$ & 165 & 156 & 160 & 73 & angles to this. & & & & \\
\hline
\end{tabular}

The goat, Capra agagrus, indigenous in the district, is frequently represented in Cretan gems, as may be seen in Figs. 25 and $67 b$ of Evans' Cretan Pictographs, and in Fig. 16, p. 269, of Journ. Hell. Stud., XVII. (A. J. Evans). In all these the long

* The teeth present the following measurements in millimetres :-

\begin{tabular}{|c|c|c|c|c|c|c|}
\hline- & & $\mathrm{M} 3$ & M 2 & M 1 & M 1 & Pm 4 \\
\hline Antero-posterio length - & - & 25 & 26 & 20 & 20 & 15 \\
\hline Antero-transverse width & - $\quad-$ & 24 & 21 & 21 & 20 & 一 \\
\hline Postero-transverse width - & - & 23 & 20 & 21 & 20 & 20 \\
\hline
\end{tabular}

$\dagger$ Blasius, Fauna der Wirbelthiere Deutschlands und der angrenzenden Landes von Mitteleurope, Braunschweig, 1857, p. 485. 
simply recurved horns define the species from the Capra hircus, a goat with doubly twisted horns figured on a coin of Delphi (Ridgeway, op. cit., p. 281).

3. Ovis aries (Blasius, op. cit., p..467).-One large twisted horncore, with a basal circumference of 150, and a length of $312 \mathrm{~mm}$., belongs to the horned domestic sheep. Six upper and eight lower jaws, and numerous refuse bones broken for food, occurring in the lower stratum, may belong either to the goat or the sheep.

4. Cervus dama.-Two antlers of the fallow deer, each torn from the head, and consisting of the two lower tynes and a portion of the flattened palm, were found. The smaller of these has been hacked off the head.*

The palm is broken off in both specimens. The flattening of the base of the second antler and the flattening of the upper part of the beam above it differentiate these two antlers from those of red deer (Cervus elaphus), with which in other particulars it bears a superficial resemblance.

5. Sus scrofa.-Three skulls of boar, found in the upper stratum, in the atriun, and very nearly perfect, present the following measurements :-

Measurements of Skulls of Domestic and WiLd Boar.

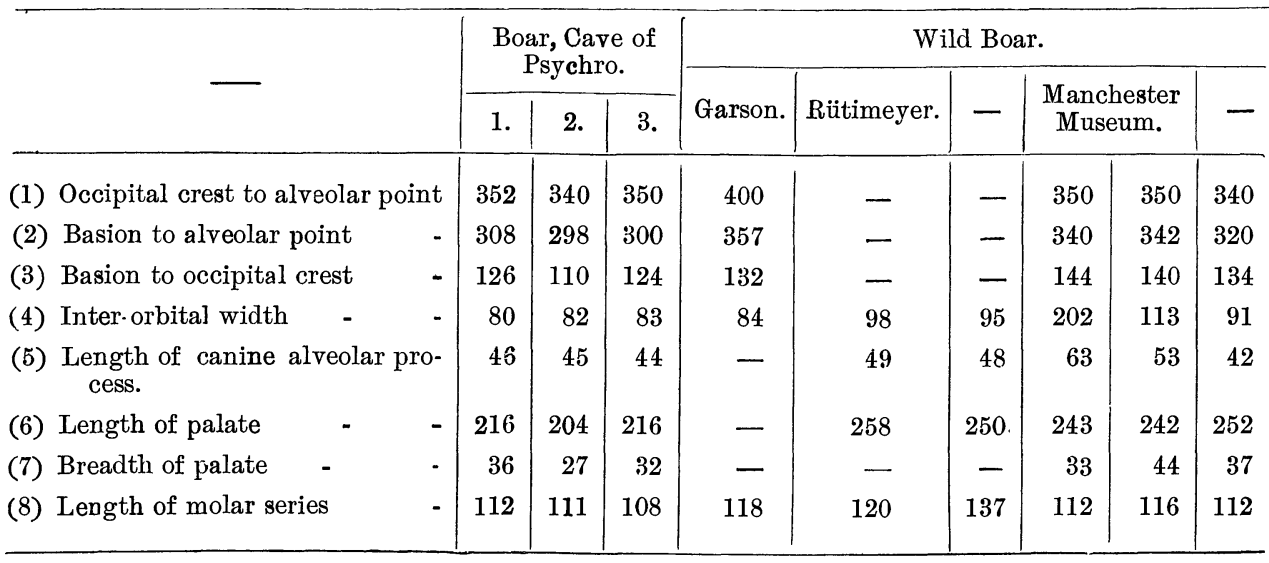

MEASUREMENT OF TEETH OF BOAR.

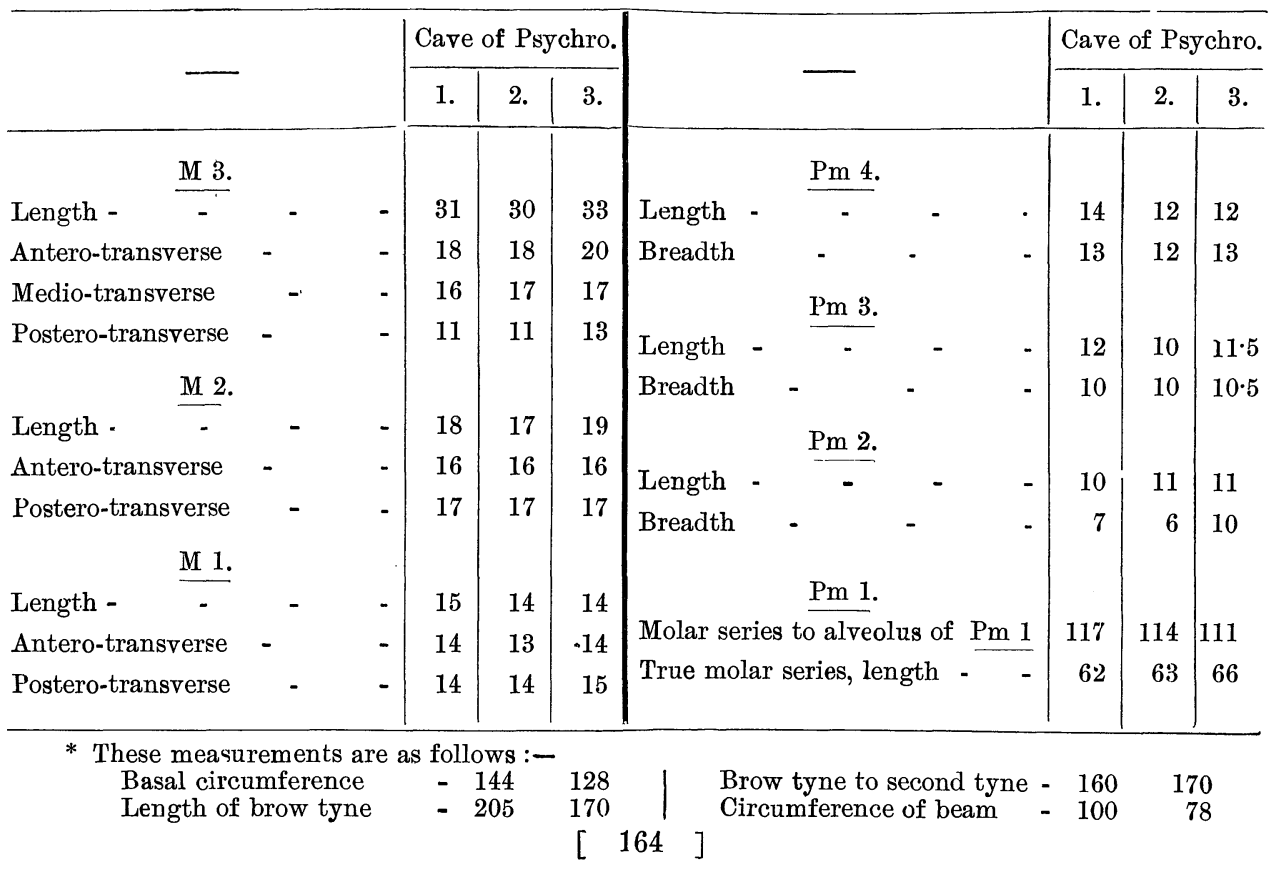


On a comparison of these skulls with those of wild boar described by Rütimeyer (Fauna der Pfahlbauten der Schweitz, V., pp. 28, 56) I find that they are smaller and without the strong muscular ridges and crests which differentiate the wild from the domestic variety. The tusks, too, are proved by the small size of the canine socket to be considerably smaller, although unfortunately the canines themselves have been removed. This conclusion is confirmed also by the comparison of the measurements of the typical wild boar selected by Dr. Garson (see Pitt-Rivers' Excavations in Cranbourne Chuse, II.: Tables of Test Animals) and with three skulls of wild boar in the Manchester Museum, Owens College. They may therefore be referred to the domestic boar, which occurs, as Dr. A. J. Evans notes, among the Cretan pictographs.

The remains of the domestic hog also are represented in the lower stratum of gravel by a lower jaw with three molars, a lower canine, an incisor, two broken bones, and the shaft of a long bone belonging to a sucking pig. These are in the condition of ordinary refuse bones.

6. Canis familiaris.-The last animal to be added to the above list is a small variety of dog, represented by an upper jaw with an abnormal upper true molar, discovered in the lower stratum of gravel.

The remains of all the animals found in the upper stratum, the domestic ox, the goat, the horned sheep, the fallow deer, and the hog were parts of offerings to Zeus, while the dog from the lower stratum may belong to an earlier period in the history of the cave. when it was used as a habitation and before it was used as a shrine of the Dictæan Zeus. The perfect condition of the offerings contrasts strongly with the fragmentary remains of the refuse heap.

W. BOYD-DAWKINS.

\section{Eskimo.}

Tocher.

Note on some Measurements of Eskimo of Southampton Island. A Paper read at the Belfast Meeting of the British Association, September 115 15th, 1902. By J. F. Tocher, F.I.C.

In the following note the results are given of an analysis of the measurements of 35 adult male Eskimo taken at my instigation by Captain A. Murray and Mr. W. e. Tocher of the whaler "Active" at Southampton Island, Hudson's Bay, on the 24th August, 1901. These figures will be useful for comparison with the numerous measurements of Eskimo skulls, while they are interesting in themselves, being confirmatory to a large degree of former measurements of the living head. The measurements recorded were those of stature, maximum head (glabello-occipital) length, and maximum head breadth. The colour of the hair and eyes, the shape of the nose and face, and the appearance of the lips and cheek bones were also recorded. Observations were made on eight male children, one half-breed male, and one female, but are not dealt with here. The average of each dimension, the mean cephalic index, and the standard deviation have been calculated aud contrasted where possible with former results. The standard deviation of a group from the average-a method of ascertaining the purity or otherwise of race already applied in a former paper-is exceedingly valuable, as the smaller the deviation is, the nearer the group approximates to the average characteristic. The average stature of the 35 Eskimo was $1,620 \mathrm{~mm}$. The stature varied from 1,486 mm. to $1,740 \mathrm{~mm}$. The greatest individual deviation was $134 \mathrm{~mm}$. below the mean. The standard deviation amounted to $68.4 \mathrm{~mm}$. or 4.2 per cent. The average head length and breadth of the group amounted to $192.4 \mathrm{~mm}$. and $148.5 \mathrm{~mm}$. respectively, the standard deviation in each case being $6.3 \mathrm{~mm}$. and $4.84 \mathrm{~mm}$. or 3.3 per cent. in both cases. The head lengths ranged from 179-205 mm., and the breadths from 140-161 mm. The cephalic index of the group was $77 \cdot 2$, with a standard deviation of $8 \cdot 36$ or $2 \cdot 89$ per cent. The cephalic index of individuals ranged from 69 to 82 , 